\title{
STRATEGIES IN REDUCING AHMAD DAHLAN STUDENTS’ ANXIETY IN SPEAKING
}

\author{
${ }^{1}$ Megawati Basri, Balqis Husain ${ }^{2}$, Fahmi Djaguna ${ }^{3}$ \\ ${ }^{1,2}$ Program Studi Pendidikan Bahasa Inggris Universitas Pasifik Morotai \\ ${ }^{3}$ Program Studi Pendidikan Guru dan Sekolah Dasar \\ Universitas Pasifik Morotai \\ correspondence email : megawatibasri065@gmail.com
}

Received: May 25, 2020 Revised: May 28, $2020 \quad$ Accepted: June 3, 2020

\begin{abstract}
The study aims to find out the strategies or ways of reducing student anxiety in speaking English. There are six selected students based on observation results to be interviewed. This research is done by a qualitative method with a descriptive approach. The results of this study show that following the English community, avoiding eye contact with friends or lecturers, confident, relaxing, and relaxed and often practicing for individual participants can reduce student anxiety in English speaking.
\end{abstract}

Keywords: reducing anxiety, students' speaking, strategy.

\section{INTRODUCTION}

English is an international language that must be mastered by educators and learners. However, in Indonesia, English is a foreign language, so many schools and colleges rarely use English in its teaching. This causes students difficulty in mastering English especially in speaking. According to (Basri, 2019) in speaking English, students try to communicate in their limited abilities.

In speaking English especially in the classroom, students are limited by their ability as they may be afraid of being wrong or embarrassed because they are ridiculed by classmates and lecturers. Since conducting research observations, students of Ahmad Dahlan English at third semester, researchers found many factors that influenced the mistakes that were made when speaking English in the classroom. As such, they do not have enough vocabulary, nervousness, lack of 
confidence and are not fluent in speech; these are some factors that affect student jealousy

\section{METHOD}

This study was held at the University of Ahmad Dahlan (UAD) in the third Semester of the English language department which contracted Speaking and Debate courses. This research is a qualitative method with a descriptive approach and the data gathered through observation and interviews. Only six students were chosen to be interviewed, these students experienced anxiety when they were conducting in-class speaking activities.

The observation was conducted in two classes; class $\mathrm{E}$ and class $\mathrm{H}$. The observation was held on December, 2017. The observation was carried out during the teaching and learning process when participants performing oral communication activities.

The researcher observed the class in order to she could interview the students based on the result of the observations. The interview was conducted on 13th of December until 16th of December 2017. The interview was held on different places.

\section{RESULT AND DISCUSSION}

a) Need more support from the teacher

One of the concerns as a strategy to reduce anxiety when speaking English is the support from the teacher. The Respondent 1 comments that the amount of material to be covered in one semester is excessive, remarking:

"My weakness is not able to speak in public; it is hard to speak English. I want to be trained to speak. I mean like individual presentation, no partner. I am a bit scared but it does not matter. If I am doing a presentation alone, what I fear is during the question and answer session because sometimes my classmates ask the hard question for me, and the other reason is my lecturer not only teaches about speaking but also about listening, she teaches us from the first semester and then she teaches listening more than speaking so Ifelt my English speaking is not enough”.

From the extract of interview above, the participant believe that the most disturbing aspect in the class is directly related to the teacher itself. She thinks that the speaking class is not enough to develop her capability when speaking English. 
The teacher should teach more about speaking and does not make peer activity too much in the speaking class. Therefore, these interviews suggest that the role of the teacher is a paramount in alleviating anxiety. (Radhia, 2016) suggest that "teachers play a vital role in helping their students to decrease their anxiety by applying certain strategies that are significant and effective.

\section{b) Sense of Community}

There are some students who give the strategies for coping with anxiety through activity group. They believe that group work and study groups can reduce anxiety for some. For instance, the respondent 3 says that:

"in my opinion, our daily activity should use English. Sometimes, it does not matter to combine with Bahasa because our vocabulary and grammar are still lack for example I go to school and we do not know about the word of 'school' it can be repaired by our friends. I suggest that every activity which is done in the classroom should be in English".

While, respondent 2 stated that

"my idea, if we gather with our friends we should use English for example like I always meet up with my friends; Janu, Amin and Bima, we always try to speak, when I am with them I do not felt nervous to speak English so let's practice English with your classmates!"

And the Respondent 5 said "If I am with my friends, we usually make a discussion group to practice English. For example there are two people who dare to speak English in each group. We usually use English but sometimes we combine with Bahasa".

The extract of interviews above indicates that classroom activities, communality and friendship among the students themselves manifest ease the students anxiety. The students believe that classroom activities that the students should use English in their class and sense of community can be good strategies for coping anxiety when speaking English.

These strategies can reduce the anxiety among the students and develop their confidence to participate in the classroom. According to(Yalçn \& İnceçay, 2014) "type of grouping showed that students felt more comfortable because they helped each other and by doing so built a sense of solidarity. Another advantage of group-work was the increased interaction between students in the target language and the student-centered classroom environment". 


\section{c) Creating Relaxed Condition}

In this case, the participant 4 and 5 believe that enjoying the learning process may help to reduce anxiety in the classroom. The Respondent 4 said "Be patient, let me think first. I think the tips for not tense in English class is not too seriously, be relax and enjoy the class. I am a typically ignore so I do not care if my classmate laughed at me. Just smile and ignore them".

While, it supported by Respondent 5, she noted "It depends on them. There are some people who feel normal when they are wrong in speaking but for myself, I felt uncomfortable and shy. It is better to enjoy your English class so relax your English class".

Positive thinking and relax can be the best strategies to reduce their anxiety when in the speaking class. Respondent 5 suggests that trying to enjoy the tension, ignoring, and not to be seriously, it can be a tactics to reducing anxiety when speaking English. Meanwhile, the participant 5 anticipates that when she feels anxious in speaking English she creates relaxation condition such as enjoy the class, even you feel embraces and nervous, do not show your frightened. She believes it can be a good strategy to reduce anxiety when speaking English in the classroom. This suggests supported by (Bashir, 2015) says "The environment of the classroom should be friendly and relaxed".

\section{d) Using Game}

There is only one student who believes that game can reduce the anxiety when speaking English in the classroom. The Respondent 6 suggests that some classroom activities named as game $\mathrm{v}$ can be an effective strategy for coping anxiety. She said

"It is betterfor using the game in the classroom, so the class will be more fun. The game should use English so we can learn through the game itself. If the class is too seriously, it considers that we will feel stressful. So I think that game can be the good way to make the English class less stressful.

Based on the statement above, the student feels more comfortable because game can be an effective strategy to reduce her anxiety in the classroom. She believes that playing games in English class can be reduce her nervous and it can be the most favorite activities in English class. It is not only attracting the 
students' attention but also provoke students' anxiety to some extent. The teacher should design and use game properly to foster English learning in a more pleasant and less pressure environment. (Radhia, 2016) says "communication games are useful strategy that has a great impact on enhancing EFL students' speaking skill. Because it is an ideal way to increase the interaction between students, motivated them, decrease their anxiety, and build their self confidence in an enjoyable manner. Communication games are mainly useful because they provide students with the opportunity to speak using the target language and maximize interaction in the language classroom".

\section{e) Avoiding Eye Contact}

There is one student suggests the way to reduce his anxiety when speaking English in the classroom. The Respondent 2 said"

(when I am thinking in my brain, I cannot be concentrated in one style. So I look at other places, such as the floor, wall and even the roof. That's way makes me notfeeling panicky".

These interviews suggest that avoiding eye contact with the audience or even the teacher is a typical non-verbal reaction to reduce anxiety when speaking English in the classroom. Sometimes, when the students perform in front of the class, they look down and pretend to busy themselves. The participant does not see face to face with their classmates when speaking, so he does not feel nervous.

\section{CONCLUSION}

Students of the third semester of English education, University of Ahmad Dahlan have a way or strategy to reduce student anxiety in English speaking. It can be concluded that, students should reduce their anxiety by doing what they think can cope with their anxiety because if continuously in letting, it will be very influential on their success in learning also they have to improve their vocabulary list, grammar, pronunciation, and have English language practice. While the English lecturers are expected to understand the anxieties of their students, such as tenses, shaking, lack of confidence and nervousness. Because the students ' anxiety levels differ from each other. As far as teachers don't call the student 
names in high notes when asking them to speak English, or even calling them without naming, it can reduce their anxiety. They can create a community of English students and lecturers.

\section{REFERENCES}

Ahmed, N. F. (2016). An Exploration of Speakimg Axienty with Kurdish University EFL Learners. Vol.7, No.(Speaking anxiety), 99-106. www.iiste.org

Ansari, M. S. (2015). Speaking Anxiety in ESL/EFL Classrooms: A Holistic Approach and Practical Study. International Journal of Educational Investigations Available Online @ Www.ijeionline.com, 2(4), 38-46. www.ijeionline.com

Bashir, S. (2015). A Study of Second Language Speaking-Anxiety among ESL Intermediate Pakistani Learners International Journal of English and Education. June.

Basri, M. (2019). Faktor Kecemasan Siswa Dalam Berbicara Bahasa Inggris pada Mahasiswa Universitas Ahmad Dahlan Yogyakarta. Jurnal Mitra Pendidikan, 3(11), 1285-1297. http:/ejurnalmitrapendidikan.com/index.php/e-jmp/article/view/639

Basri, M., Djaguna, F., \& Husain, B. (2020). Anxiety Level in English Speaking Among Ahmad Dahlan Students. Lire Journal (Journal of Linguistics and Literature), 4(1), 40-49. https://doi.org/10.33019/lire.v4i1.57

Gursoy. (2016). International Journal of Language Academy FOREIGN LANGUAGE ANXIETY AMONG EFL UNIVERSITY STUDENTS AND THEIR DEDUCTIVE / INDUCTIVE LEARNING STYLE. 4, 72-87. http://ejurnalmitrapendidikan.com/index.php/e-jmp/article/view/639

Hashemi, M., \& Abbasi, M. (2013). The Role of the Teacher in Alleviating Anxiety in Language Classes. 4(3), 640-646.

Indrianty, S. (2016). Students 'Anxiety in Speaking English ( a Case Study in One Hotel and Tourism College in Bandung ). Eltin, 4(I), 28-39. http:/ejournal.stkipsiliwangi.ac.id/index.php/eltin/article/view/337

Melouah, A. (2013). Foreign Language Anxiety in EFL Speaking Classrooms: A Case Study of First-year LMD Students of English at Saad Dahlab University of Blida, Algeria. Arab World English Journal, 4(1), 64-74.

Radhia, R. (2016). The Impact of Language Anxiety on EFL Students' Speaking Skill The case of first year LMD students at the English Branch in the University of Mohamed Kheider Biskra.

Sutarsyah. (2017). An Analysis of Student's Speaking Anxiety and its Effect on 
Speaking Performance. IJELTAL (Indonesian Journal of English Language Teaching and Applied Linguistics), 1(2), 143-152. https://doi.org/10.21093/ijeltal.v1 i2.14

Taysi, E. (2015). International Journal of Languages 'Education and Teaching LANGUAGE: THE EXAMPLE OF GAZI UNIVESITY TURKISH. 3(3), 1062-1073.

Yalçı, Ö., \& İnceçay, V. (2014). Foreign Language Speaking Anxiety: The case of Spontaneous Speaking Activities. Procedia - Social and Behavioral Sciences, 116, 2620-2624. https://doi.org/10.1016/j.sbspro.2014.01.623 